\title{
WIGS, SKELETONS, BIBS, BANDS, AND BUNDLES: AN ALBERTAN BARRISTER DECIPHERS THE ENGLISH COURT OF APPEAL (CRIMINAL DIVISION)
}

\author{
LAURA HOYANO*
}

There are a number of features of British criminal appeals which differ from the Canadian justice system. This article explores these differences by reviewing the changes and customs adopted by the English Court of Appeal (Criminal Division).
Les procédures d'appel en matière criminelle de la Cour d'appel anglaise comportent certaines différences par rapport à celles du système juridique canadien. Cet article examine les changements et les coutumes adoptées par la chambre criminelle de la Cour d'appel anglaise.

Until 1907, for English and Welsh criminal defendants, the pronouncement of conviction and sentence meant doom, because no appeal as of right lay from either judgment. ${ }^{1}$ When the trial judge placed the black kerchief on top of his wig to pronounce a capital sentence, the carpenters were busy constructing the gallows, and the sentence was executed unmercifully swiftly.

Although twenty-first-century criminal defendants are unlikely to know it, they enjoy their rights of appeal to a higher court in part to the most famous detective writer of all time: Sir Arthur Conan Doyle, whose campaign over the wrongful conviction of solicitor George Edalji is chronicled by Julian Barnes in his novel Arthur \& George. ${ }^{2}$ Her Majesty's Court of Appeal in England, established in 1875, did not hear criminal appeals on points of law or fact until $1907 .{ }^{3}$ So notwithstanding that Canadian lawyers view their court system as emanating from centuries of British justice, the Alberta Court of Appeal is only seven years younger than its English counterpart in respect of its criminal jurisdiction.

There are a number of features of British criminal appeals which strike a Canadian lawyer as distinctly odd. Most importantly, unlike in Canada, British justice does not acknowledge the concept of a wrongful acquittal, and so the Crown has no general right of appeal from an acquittal, even if it is tainted by serious legal errors.

Limited inroads into this principle have recently been made, by statutory repeal of double jeopardy for serious offences, where a second trial can be held if the prosecution has acquired new and compelling evidence of guilt, and by conferring on the prosecution the right to appeal "terminating rulings" such as exclusion of a confession or improperly obtained evidence, which cause a trial to collapse. The Attorney General can refer a case to the Court of Appeal if there is concern that an erroneous ruling of law may become embedded in practice, but this cannot affect the acquittal verdict which still stands even if

BA (Hons History), MA, JD (Alberta), BCL (Oxon). Associate Professor of Law, University of Oxford; Senior Research Fellow, Wadham College Oxford; Fellow of the Honourable Society of Middle Temple; door tenant of Red Lion Chambers in London; Barrister \& Solicitor (Alberta) (retired).

$1 \quad$ The Court for Crown Cases Reserved heard cases only on wholly discretionary referrals from the trial judge himself, and could only deal with points of law.

Julian Barnes, Arthur \& George (New York: Vintage International, 2005).

Criminal Appeal Act, 1907 (UK), 7 Edw VII, c 23. The Court was constituted as the Court of Criminal Appeal until 1966, when it was superseded by the Criminal Division of the Court of Appeal of England and Wales. 
tainted by such an error. These severely restricted Crown appeal rights result in an imbalance in the jurisprudence, with trial judges able to make errors favouring the defence, such as perpetuating myths about child witnesses and sexual offences, with virtual impunity.

Second, virtually all criminal appeals are from trials involving lay triers of fact. Some 92 percent of all criminal cases are tried before lay magistrates, who act as triers of the law but are very dependent upon the legal advice of their law clerk, and also as triers of fact. All indictable offences are tried in the Crown Court before a jury, there being no right to elect trial by judge alone. Hybrid offences (known as "either way”) may be tried in either court, and the magistrates may refer a case to the Crown Court if they believe their sentencing powers are inadequate.

The British cling fiercely to trial by jury — although they accept so-called majority verdicts (of guilty or not guilty) of 10 to 2 in England, and 8 to 7 in Scotland. There is legislation on the books to have complex fraud trials heard by a judge sitting alone, but so controversial did this inroad prove that the legislation can be brought into force only with consent of Parliament, which was not forthcoming, and it has now been repealed by the Protection of Freedoms Act 2012. ${ }^{4}$ Statutory power to order trial by judge alone in the case of jury nobbling has been invoked only once to date, where two lengthy and expensive trials had collapsed for this reason.

Third, by convention there are no dissenting judgments in criminal appeals, although they are very common in civil appeals. No Court of Appeal judge has been able to explain to me the source or reason for this convention. The Supreme Court of the United Kingdom and its predecessor the Appellate Committee of the House of Lords do not feel constrained by this convention, and will permit dissents in criminal cases.

Fourth, the default remedy for an unsafe verdict (the test in England and Wales) or a miscarriage of justice (the Scottish test) is to quash the conviction. A finding that the verdict was the result of an unfair trial under Article 6 of the European Convention on Human Rights does not automatically make the verdict unsafe or a miscarriage of justice. ${ }^{5}$ Unfortunately in my view, retrials are far less common in England than in Canada, unless there is a hung jury. In practical terms, the prosecution has only one chance to get their case right.

Fifth, as a statutory court, the Court of Appeal has no power to overrule its own previous judgment if it forms a view that that judgment is now erroneous, perhaps because of inconsistency with a judgment of the European Court of Human Rights, of which it must take account under section 3 of the Human Rights Act $1998 .{ }^{6}$ Its only recourse is to grant leave to appeal to the Supreme Court which can correct the error.

Because of the very large size of the Court of Appeal, this means that different panels may reach conflicting conclusions, which cannot be resolved unless a subsequent case goes to the

(UK) 2012, с 9.

Laura Hoyano, "What Is Balanced on the Scales of Justice? In Search of the Essence of the Right to a Fair Trial” (2014) 1 Crim L Rev 4; Council of Europe, Convention for the Protection of Human Rights and Fundamental Freedoms, 87 UNTS 103, CETS No 5 (1950), art 6 [ECHR]. (UK) 1988, c 42, s 3 . 
Supreme Court. ${ }^{7}$ This can create major confusion for barristers, one example being the issue whether allegedly false allegations made previously by a sexual assault complainant are subject to the restrictions on cross-examination on previous sexual history or to the restrictions on bad character evidence; the conflict in judgments has not been resolved for several years, so cautious counsel now take the pragmatic route of applying for leave under both statutory provisions.

Sixth, the Court of Appeal has a large measure of control over cases going to the UK Supreme Court. Leave to appeal can be sought from the same panel which has just disappointed that party with its judgment, and this occasionally is given where the Court of Appeal considers the matter to be of major public importance, as in the Nicklinson case, where leave was granted by the Master of the Rolls on the issue of whether necessity is a defence to assisting the suicide of a totally disabled person. ${ }^{8}$ Counsel may also request the panel to certify a question of law of public importance, on the back of which they can seek leave to appeal from a single judge of the Supreme Court. However, I was recently startled to discover that the Court of Appeal can block any appeal to the Supreme Court simply by refusing to certify that question. I am currently involved in a child trafficking case before the European Court of Human Rights in Strasbourg in which the applicant, a trafficked Vietnamese child convicted of working in a cannabis factory, contends that the power of the panel to block further appeal prevented his access to justice under Article 6(1) of the ECHR. ${ }^{9}$

Although the courts and Bar like to think that they are very progressive, many arcane traditions persist. The Lord Chief Justice, in charge of the Criminal Division of the Court of Appeal, is still the most senior judge in England and Wales, followed by the Master of the Rolls in charge of the Civil Division. So the President of the UK Supreme Court trundles along in third place in judicial processions. That said, the copious gold thread on their ceremonial robes is equally blinding in the sunlight.

Briefs are still tied with ribbon, white for the prosecution and pink for the defence (and other private clients), but now with the volume of written material for trials and appeals, usually only instructions from the instructing solicitors are decorated this way. Appeal materials such as extracts from the evidence and the authorities are usually put into tabbed binders ("folders" in UK office terminology, which I always forget when ordering supplies), but however they are housed, they are dubbed "bundles." Appellate facta are called "skeletons," or colloquially, "skellies," but counsel often hand up written "notes” to the court by way of supplementary submissions when points arise during oral argument.

While wigs have been abandoned in the Civil Division of the Court of Appeal, and the Justices of the UK Supreme Court are adorned only in business suits to hear appeals, the full

There are 38 Lord Justices of Appeal (the male title also applies to the seven women on the Court of Appeal) plus five Heads of Division. Criminal panels for routine appeals are made up of one Lord Justice plus two High Court judges. Female High Court judges are known as “Mrs Justice,” and women barristers are commonly addressed as “Miss,” regardless of marital status. In May 2014 Alison Russell QC was appointed to the High Court and announced that she is to be addressed as Ms Justice Russell. Whether her precedent is followed, time will tell. I still prefer the more sonorous Alberta title of "Madam Justice” and have slipped occasionally in addressing UK judges in that way, to their bemusement. This judgment has now been issued: R (Nicklinson) v Ministry of Justice, [2014] UKSC 38, [2014] 3 WLR 200 [Nicklinson]. Supra note 5. 
regalia is still worn by counsel and judges in the criminal courts. Wigs are supposed to confer dignity, but I think that they make the wearers resemble sheep, and I find it difficult to keep a sober countenance, especially when "full bottom" wigs are worn by judges and QCs ("Silks") for ceremonial occasions such as the Opening of the Assizes, along with knee breeches, stockings, and buckled patent leather shoes, with silk gloves — required to be carried in one hand, not worn.

One justification for wigs is that it confers a measure of anonymity on those wearing them. I do have one piece of empirical evidence to support this: a Crown Court judge told me that she found herself in a queue at the lunch break at the till of a food store, with the defendant (on bail) standing behind her, but he did not recognize her, to her immense relief (I did not ask what she was purchasing...).

Notwithstanding the wigs, English barristers are rather more casual than Canadian barristers in what they wear under their gowns. Business suits are often worn rather than the full striped court dress to which Albertans are accustomed. While some still like to struggle with fastening their wing collars onto their court shirts with collar pins, many just take the shortcut of wearing a "bib,” incorporating a wing collar and shirt front and "bands" (that is, tabs) in one go, which can be worn tucked into a black dress or business jacket. Even striped coloured shirts often make an appearance, which I expect would appall the Justices of the Alberta Court of Appeal!

The Court of Appeal sits in the grandiose Victorian Royal Courts of Justice in London, surrounded by the Inns of Court housing barristers in very crowded offices (often three to a room). The Lord Chief Justice and the Master of the Rolls each have their own court rooms, the walls of which are lined with leather-bound law reports.

There are three rows of lawyers' benches, the front for Silks, the second row for Juniors, and the third row for instructing solicitors. These are long wooden benches with no exit at the other end; when I was in the Court of Appeal for a consolidated hearing of four cases with thirteen counsel last May, everyone had to slide down the bench and out to allow a latecomer in, or to let someone fetch forgotten notes. No wonder the benches are so burnished by generations of barristers' bottoms.

The tables are also long pieces of oak attached to the back of the bench ahead, barely 18 inches wide, with no power supply for laptops and no space for the bulky bundles, and only the Silks have access to a podium. So counsel resort to putting the cardboard boxes in which their clerks have trundled over the appeal materials up on the table sideways, to store the folders. Providentially this has the advantage of barring the view of neighbouring counsel of one's argument, and might even serve as a sound barrier to whispered conferences with the solicitors behind. This expedient does make the middle of the very grand court rooms look rather like a grocery store.

But I venture to think that no counsel would prefer to appear in the sterile modern electronically-equipped court rooms over the Lord Chief Justice's own majestic Victorian court room. And, perhaps surprisingly, justice is delivered with remarkable swiftness, efficiency, and effectiveness. 